\title{
Koncepcja percepcji środowiska w ujęciu Tima Ingolda ${ }^{1}$
}

\author{
Hanna Koczwara, Zbigniew Wróblewski* \\ Wydział Filozofii, Katolicki Uniwersytet Lubelski Jana Pawła II \\ Al. Racławickie 14, 20-950 Lublin \\ *zbyl.wroblewski@gmail.com• ORCID 0000-0003-4477-6903
}

\begin{abstract}
Streszczenie
Głównym celem artykułu jest rekonstrukcja koncepcji percepcji środowiska w ujęciu Tima Ingolda, szkockiego antropologa kulturowego. W pierwszej części artykułu przedstawiono historyczny i teoretyczny kontekst ujęcia percepcji środowiska oraz dokonano rekonstrukcji podstawowych założeń teoretycznych antropologii środowiska w ujęciu T. Ingolda. Najważniejszymi elementami tego kontekstu są m.in.: ekologiczna koncepcja percepcji J. Gibsona, koncepcja Umweltu Jakoba Johanna von Uexkülla, idee przekształcania i zamieszkiwania środowiska wg. Heideggera, koncepcje ucieleśnionego poznania i umysłu rozszerzonego. Rekonstrukcja koncepcji percepcji środowiska jest skoncentrowana na eksplikacji trzech głównych idei: życie w ruchu, zamieszkanie oraz kształtowanie umiejętności. W części drugiej artykułu przedstawiono aplikację koncepcji percepcji środowiska do studium przypadku: percepcja lasu i ekologiczne podejście do materiału.
\end{abstract}

\section{Słowa kluczowe}

T. Ingold, percepcja środowiska, percepcja lasu, ekologia materiału, antropologia środowiska

\section{Uwagi wstępne}

Percepcja środowiska nie jest zagadnieniem prostym m.in. dlatego, że jego sformułowanie, wyodrębnienie elementów składowych i ich ustrukturalizowanie, sformułowanie teorii opisujących i wyjaśniających wymagają sięgnięcia do bogatego schematu pojęciowego zawierającego pojęcia złożone treściowo pod względem systematycznym

1 Artykuł został przygotowany w ramach projektu badawczego finansowanego przez Narodowe Centrum Nauki, Harmonia 6 (UMO-2014/14/M/ HS1/00436 na lata 2015-2018) pt. „Zaangażowanie języka, czynników kulturowo specyficznych i potocznych intuicji w zdolność czytania w umyśle i poznaniu społecznym". i historycznym, np. pojęcia środowiska, organizmu, przedmiotu, poznania lub percepcji. Każde z takich pojęć może stać się przedmiotem wielotomowych opracowań monograficznych, w których koniecznie pojawią się odniesienia do klasycznych dyskusji na temat relacji organizm-środowisko, natura-kultura, człowiek-środowisko przyrodnicze i kulturowe, umysł-ciało, obiektywne-subiektywne. Tematy te implikują odpowiednie rozumienie podstawowych pojęć w ramach dyscyplinarnych determinacji, np. rozumienie środowiska w ramach psychologii środowiskowej, nauk ekologicznych lub antropologii kulturowej. Z metodologicznego punktu widzenia ostatniej 
z wymienionych dyscyplin (antropologii kulturowej) możemy uzyskać interdyscyplinarny przegląd wyróżnionych kategorii składowych percepcji środowiska. Instruktywnym przykładem takiego ujęcia jest koncepcja Tima Ingolda ${ }^{2}$, szkockiego antropologia kulturowego, który oryginalnie połączył kilka wątków z obszaru ekologii, psychologii i filozofii w spójną całość. Percepcja środowiska w ujęciu Ingolda wiąże się $\mathrm{z}$ postrzeganiem danych $\mathrm{w}$ otoczeniu, organizacją tych treści oraz reagowaniem na nie, co dobrze oddaje metafora doświadczenia „uzmysłowionego-organizmu-poruszającego-się-w-środowisku".

Głównym celem artykułu jest rekonstrukcja koncepcji percepcji środowiska w ujęciu szkockiego antropologa oraz jej aplikacja do opisu percepcji wyróżnionego typu środowiska, jakim jest las. W pierwszej części artykułu przedstawimy historyczny i teoretyczny kontekst ujęcia percepcji środowiska oraz dokonamy rekonstrukcji podstawowych założeń teoretycznych koncepcji Ingolda, dotyczących postrzegania środowiska. W części drugiej artykułu przedstawimy studium przypadku: percepcję lasu i ekologiczne podejście do materiału. Od strony metodologicznej problematyka artykułu lokuje się co najmniej w dwóch obszarach problemowych: filozoficzne aspekty ontologii, epistemologii i antropologii środowiska oraz antropologiczno-kulturowe redefinicje tych aspektów, tzn. przetworzenie abstrakcyjnych pojęć teoretycznych do opisu konkretnych, kulturowo uwarunkowanych form percepcji środowiska.

\section{Kontekst historyczny i teoretyczny}

Koncepcja percepcji środowiska Tima Ingolda powstała w kontekście jego

2 T. Ingold jest antropologiem społecznym, zajmującym się relacją natury i kultury w kontekście organizmu ludzkiego usytuowanego w środowisku. Ingold swoje badania kontynuuje obecnie na Uniwersytecie w Aberdeen w Szkocji, gdzie jest dyrektorem Instytutu Antropologii. Sam jednak nazywa się „wiecznym studentem antropologii” (Ingold, 2000: $x$ ). zainteresowań biologią, psychologią, filozofią i antropologią. Jego ojciec, Cecil Torence Ingold, jeden z najbardziej wpływowych mykologów XX w., zabierał młodego Tima na spacery, podczas których zwracał uwagę chłopca na wzrost, kształt i rozwój organizmów żywych (Ingold 200o: 20-1). Opisy wzrostu i kształtowania się formy świata ożywionego uwrażliwiły młodego Tima na to, jak życie i forma ewoluują w nieustannie rozwijającej się sieci powiązań przyrodniczych. I prawdopodobnie dlatego, kiedy w 1989 r. (Ingold 1990: 5-17) antropolodzy nieśmiało jeszcze spoglądali na powiązania społeczne w kontekście świata biologicznego, dojrzały już Ingold wystąpił z pierwszą prezentacją dotyczącą rozwoju człowieka w jego sieci powiązań środowiskowych. Rozwój człowieka nie mógł być przez niego inaczej postrzegany, jak tylko w nieustannie rozwijającej się sieci wzajemnych relacji kulturowo-środowiskowych (Ingold 2000: 12). W antropologii kulturowej wpisywało się to w intensywny okres poszukiwań pojęć i koncepcji systematyzujących nowe ujęcia tradycyjnych form dualizmów opisujących relacje człowiek-środowisko. Materiału do tych teoretycznych poszukiwań dostarczały idee i teorie, które funkcjonowały już w różnych obszarach badań naukowych (nauk społecznych, humanistycznych i przyrodniczych) i dojrzewały do wykorzystania ich w nowych syntezach. Szkocki antropolog wskazuje, które idee z tego bogatego kontekstu naukowego zostały przez niego zaadoptowane w antropologii kulturowej. Najważniejszymi elementami tego kontekstu są m.in.: ekologiczna koncepcja percepcji Jamesa J. Gibsona, koncepcja Umweltu („Wokół-świata”) Jakoba Johanna von Uexkülla, idee przekształcania i zamieszkiwania środowiska według Martina Heideggera, koncepcje ucieleśnionego poznania i umysłu rozszerzonego. Od strony formalnej można ten kompleks idei uporządkować w trzech dopełniających i warunkujących się wzajemnie profilach: ontologicznym (ontologia środowiska), epistemologicznym (epistemologia 
środowiska) i antropologicznym (antropologia środowiska).

Rozpocznijmy od rekonstrukcji tła ontologicznego, w którym sformułowano idee na temat natury, struktury i funkcjonowania środowiska w ujęciu relatywnie ogólnym (bez szczegółowego zdeterminowania, o jakie środowisko i organizm chodzi). Fundamentalnych idei na temat natury środowiska dostarczyły Ingoldowi prace niemieckiego biologia Jakoba Johanna von Uexkülla i jego koncepcji środowiska ujmowanego jako Umwelt (Ingold 200o: 176-178). Koncepcja Umwelt („Wokół-świata”) charakteryzowała środowisko w relacji do organizmu, który aktywnie postrzega, działa i kształtuje swoje otoczenie. Na Umwelt składa się szereg elementów w otoczeniu, które są indywidualnie wartościowane przez organizm. Natomiast znaczenie przypisywane elementom w środowisku przez żywe organizmy zależy od ich aktualnych potrzeb determinowanych w ramach gatunku. Tak więc Umwelt jest środowiskiem doświadczanym jednostkowo w ramach normy gatunkowej. Każdy organizm ma swoje własne odniesienie wartościujące elementy otoczenia i w ten sposób tworzy Umwelt, czyli swoje subiektywne uniwersum. Takich subiektywnych uniwersów jest wiele; nie ma jednego uniwersalnego i obiektywnego środowiska, jednego „Wokół-świata”, w którym żyją wszystkie organizmy. Różnorodność odbieranych światów, von Uexküll ilustruje na przykładzie dębu zamieszkanego przez różne zwierzęta: „Lis mieszkający w korzeniach drzewa będzie zwracał uwagę głównie na to, co dzieje się u stóp jego nory. Sowa będzie znała najlepiej rozgałęzioną część korony drzewa. Wiewiórka natomiast będzie biegać od jednego drzewa do drugiego. Mrówki mogą się trzymać samej kory. Chrząszcz będzie traktował drzewo jako miejsce do składania jaj. Każde z tych stworzeń inaczej postrzega drzewo, wokół którego rozgrywa się jego życie. Dąb ten może więc stanowić schronienie dla lisa, wsparcie dla sowy, plac zabaw wiewiórki, chodnik dla mrówki, czy też miejsce składania jaj dla chrząszcza. Tym samym drzewo to figuruje jako zupełnie inny rodzaj środowiska, Umwelt, dla swoich mieszkańców. I choć wszystkie wymienione zwierzęta stanowią jego istotną część, żadne z nich nie zastąpi samego drzewa" (von Uexküll 1957: 76-9, za: Ingold 200o: 276-277). Co więcej, mieszkańcy drzewa: lis, sowa, wiewiórka, chrząszcz i wiele innych, poprzez swoje działanie osiedlenia, kształtują warunki dla rozwoju drzewa. Przez wieki organizmy będące niemal nieodłączną częścią drzew mogły ukształtować ich odpowiednią formę, np. rozgałęziony kształt korzeni. Ingold zauważa, że podobnie na środowisko mogą wpływać ludzie zamieszkujący środowisko przyrody, a ogólniej rzecz ujmując: tak wygląda wzajemne kształtowanie się organizmów i środowiska (Ingold 200o: 176-179).

Znaczący wpływ na koncepcję Ingolda miała psychologia ekologiczna Jamesa Gibsona, autora An ecological approach to visual perception (1979). Psycholog ekologiczny zwrócił jego uwagę na istotne zależności pomiędzy środowiskiem spostrzeganym a samym spostrzegającym (Ingold, 200o: 166-8), które można lapidarnie sformułować następująco: podobnie jak nie istnieją organizmy bez środowiska, nie istnieje środowisko bez organizmów (Ingold 2000: 20). Według Gibsona, widzenie w środowisku jest możliwe bezpośrednio w każdym momencie i nie wymaga dodatkowego przetwarzania informacji z otoczenia. W związku z tym wszystkie organizmy wyposażone w aparat wzrokowy są zdolne do bezpośredniej percepcji środowiska. W tym ujęciu środowisko z perspektywy organizmu spostrzegającego nie jest światem fizycznym (istniejącym w sobie i dla siebie), ale światem fenomenalnym organizmu, w którym należy wyróżnić trzy fizyczne aspekty umożliwiające widzenie. Należą do nich: medium (medium), powierzchnia (surface) i substancja (substance). Medium jest otoczeniem pośredniczącym, np. powietrze, w którym regulowana jest odległość pomiędzy obserwującym a obiektem obserwowanym; umożliwia ono ruch i percepcję organizmu, np. przenosząc fale akustyczne, umożliwia słyszenie. Powierzchnia 
substancji wytycza jej granice, charakteryzuje się odpowiednim ułożeniem (layout), kształtem (facing) i strukturą (texture). Substancja natomiast to materiał, z którego jest zbudowany obiekt obserwowany. Znajduje się ona pod powierzchnią i nie można jej zobaczyć, nie odnosząc się do jej powierzchni. Dostrzeżenie powierzchni substancji może odnosić obserwującego do możliwości obiektu. To, co można zrobić z obiektem widzianym, jest czymś więcej niż ogół właściwości fizycznych tego obiektu widziany powierzchniowo. Taka możliwość użycia została nazwana przez Gibsona afordancja rzeczy lub miejsca, czyli taką ich własnością, która nadaje im stałe i automatycznie rozpoznawane funkcje. Afordancja określa sposób współoddziaływań pomiędzy organizmem spostrzegającym a środowiskiem spostrzeganym, np. pewne cechy środowiska umożliwiają (afford) schronienie, inne - możliwość zdobycia pożywienia. W procesie spostrzegania obiektów w środowisku organizmy zapoznają się z ich fakturą, powierzchnią i krawędziami. Afordancje są dostrzegalne we właściwościach fizycznych obiektów i niekoniecznie od razu wszystkie są postrzegane przez każdy organizm; dostrzeganie afordancji środowiska dostarcza informacji na temat ważnych funkcji środowiska, które są zrelatywizowane gatunkowo.

Kolejnych inspiracji, tym razem filozoficznych, Ingold szukał w tekstach Martina Heideggera. W Budować, mieszkać, myśleć (Heidegger 1951, tłum. polskie 1977), środowisko stanowi przestrzeń możliwą do zamieszkania. Ingold korzysta z pojęcia zamieszkania w środowisku i czyni je jednym z głównych założeń swojej koncepcji percepcji środowiska (Ingold 2000: 154). Według Heideggera, człowiek mieszka w przestrzeni, którą zbuduje, czyli w tej, której nada znaczenie. Budowanie sieci znaczeń jest związane z myśleniem, np. wartościowanie przedmiotów w środowisku jest związane z zaangażowaniem umysłowym osoby w dane środowisko. Natomiast zamieszkanie jest wynikiem myślenia i budowania. Co więcej, zamieszkanie jest rozumiane jako roztaczanie troski i stwarzanie warunków do rozwoju siebie i innych. Przede wszystkim jednak mieszkanie jest równe działaniom w świecie (Ingold 200o: 57). W swojej koncepcji Ingold odnosi się do perspektywy zamieszkania, którą stawia ponad perspektywę budowania. U Ingolda mieszkanie stanowi warunek dla budowania. W koncepcji antropologa środowisko nie powstaje ex nihilo, ale ulega stałej rekonstrukcji w wyniku zamieszkania - wartościowania obiektów i działania organizmów w środowisku. Znaczenie elementów zmienia się poprzez ich używanie. Możliwości ich użycia stanowią odniesienie do wcześniej opisanych afordancji środowiska. To jak obiekty będą wykorzystywane, decyduje o tym, jakim zmianom ulegnie dane środowisko. W ten sposób w ujęciu Ingolda, człowiek zamieszkując środowisko, zmienia charakter danej przestrzeni.

Głównym źródłem inspiracji do sformułowania koncepcji bezpośredniej percepcji środowiska jest filozofia fenomenologiczna Maurice’a Merleau-Ponty'ego. Według niego poziom percepcji i zakres odbioru zjawisk jest związany z byciem w świecie i bezpośrednim reagowaniem na to, co się $\mathrm{w}$ nim dzieje. Zdolność do reagowania jest zależna od zmysłowych odpowiedzi organizmów na bodźce środowiskowe. W swojej koncepcji Ingold nawiązuje do tego rodzaju bezpośredniego doświadczania świata i możliwości, zdolności do widzenia i „otwierania się” na świat. Według Merleau-Ponty'ego, człowiek może być w pewien sposób nieobecny w świecie, gdy tylko otworzy oczy i zapomni o swojej zdolności do widzenia. „Nieobecność" rozumiana jest tutaj jako utrata części pełnego procesu widzenia rzeczy, tzn. percepujący podmiot nie jest świadomy procesów percepcji, choć jest świadomy widzianych przedmiotów. Widziane przedmioty mogą więc przysłonić samą zdolność widzenia ich. Ingold podejmuje się zatem zadania odzyskania zmysłu wzroku w jego oryginalnej formie, czyli uzmysłowienia sobie najpierw samej zdolności do widzenia i bezpośredniego doświadczania świata (Ingold 2000: 266). Co więcej, dla Ingolda zmysły 
ze swoimi zdolnościami do doświadczania środowiska bezpośrednio funkcjonują jako całokształt systemu percepcyjnego i są zależne od ruchu organizmu w jego środowisku. Do wyżej wymienionych kwestii Ingold nawiązuje w szczególności w swoim eseju Zatrzymaj się. Patrz i stuchaj (Ingold 2000: 243-287).

Ostatnim z wymienionych tutaj źródeł koncepcji percepcji środowiska jest ekologiczne podejście do umysłu Gregorego Batesona $^{3}$. To batesonowskie ujęcie relacji pomiędzy umysłem i środowiskiem wzmocniło intuicje Ingolda w sprawie zaangażowania umysłowego organizmu w środowisko. Dla Batesona umysł jest tym, co łączy środowisko naturalne z człowiekiem kultury. Ekologia umysłu stanowi opis wzajemnego oddziaływania umysłu i środowiska, na które umysł reaguje. Stąd też umysł jest traktowany jako nieograniczony przez skórę (Ingold 2000: 3). Co więcej, umysł w koncepcji Batesona jest usytuowany w organizmie i stanowi nieodłączną część środowiska. Jego podejście ekologiczne wskazuje na dynamikę systemu poznawczego człowieka, który jest w stałej, enaktywnej relacji do środowiska. Właśnie do takiej aktywnej relacji Ingold odnosi się w swojej koncepcji percepcji uzmysłowionego organizmu w środowisku. Umysł jest tym, co łączy środowisko naturalne z człowiekiem, a to z kolei pozwala na przejście do koncepcji poznania w szerszym ujęciu nauk kognitywnych.

Poszukiwania antropologiczne Ingolda wpisują się także w kontekst współczesnych badań z obszaru filozofii umysłu dotyczący idei umysłu rozszerzonego, zapronoponowanej przez Andy'ego Clarka i Davida Chalmersa w artykule The Extended Mind z 1996 roku (Clark, Chalmers 1996). Według tej koncepcji poznanie nie jest ograniczone przez barierę ciała, a osoba poznająca i jej środowisko tworzą razem złożony system poznawczy. Ujęcie takie

3 . Gregory Bateson (1904-1980) - brytyjski antropolog kulturowy, twórca cybernetycznej teorii umysłu, autor Steps to Ecology of Mind (Bateson, 1972) i Umyst i przyroda. Jedność konieczna (1996). wychodzi poza klasyczną koncepcję kognitywistyki opowiadającą się za operacjami obliczeniowymi umysłu na reprezentacjach mentalnych. Umysł rozszerzony jest rozpatrywany jako całość aktu poznania, gdzie sytuacja poznawcza ma charakter enaktywny ze środowiskiem, a wzajemne oddziaływania mają charakter sprzężony. Szeroki system poznawczy - w tym nurcie kognitywistyki - obejmuje również propozycje poznania ucieleśnionego i zakorzenionego, odwołujące się do tradycji pragmatyczno-naturalistycznej Johna Deweya, do tradycji fenomenologiczno-egzystencjalnej Martina Heideggera i Maurice'a Merleau-Ponty'ego (Trybulec 2017). Dewey przyjmuje, w opozycji do koncepcji pokartezjańskich, że reguły racjonalności nie są absolutne, lecz kształtowane przez środowisko. Poznanie jest dla niego praktycznym, ucieleśnionym działaniem. Percepcja i myślenie są nieoderwalne od ruchu organizmu w środowisku. Pragmatyczne podejście Deweya, gdzie granica pomiędzy podmiotem poznającym a środowiskiem staje się niewyraźna, jest zakorzenione i ucieleśnione oraz stanowi inspirację dla zwolenników poznania usytuowanego. Procesy poznawcze są w stałej korespondencji z procesami zachodzaccymi w środowisku, splatają się ze sobą i stają się od siebie nieustannie zależne. Zależności stanów świadomych myśli i odniesień do czegoś w świecie są rozwijane również w myśli fenomenologiczno-egzystencjalnej Heideggera. Nadawanie znaczenia rzeczom w świecie jest widziane z perspektywy zakorzeniania człowieka w jego środowisku. U obu przedstawicieli myśli holistycznej na działalność poznawczą składają się: środowisko i relacje z jego elementami. Weryfikacja treści pomyślanych następuje jednak zawsze w działaniu środowiskowym.

Ciało podmiotu poznającego, jako reagujące i współpracujące ze środowiskiem, nadaje kształt przebiegu procesów poznawczych (Trybulec 2017). W paradygmacie poznania ucieleśnionego rozpatrywanie zachodzących procesów poznawczych jest nieoderwalne od biologicznych właściwości 
podmiotu poznającego. Budowa aparatu poznawczego wpływa na percepcję danych ze środowiska. Zależność pomiędzy środowiskiem a podmiotem poznającym jest tak silna, że zwolennicy perspektywy fenomenologicznej, m.in. Fransico Varela, Evan Thompson, Eleanor Rosh, odchodzą od tradycyjnego podziału na właściwości zewnętrzne obiektów i wewnętrzne symboliczne reprezentacje. Według nich to, w jaki sposób podmiot doświadcza świata, jest zdeterminowane wzajemną interakcją pomiędzy ciałem i jego fizjologią, zdolnościami sensomotorycznymi a środowiskiem. Podmiot poznający jest więc enaktywny, a nie obliczeniowy.

Koncepcja umysłu rozszerzonego wskazuje na komplementarność procesów wewnętrznych i zewnętrznych. Doświadczany świat jest odzwierciedlany przez wzajemne interakcje pomiędzy fizjologią organizmu, odpowiedzią sensomotoryczną i środowiskiem. Stale aktualizujące się procesy zachodzące w środowisku są w enaktywnej relacji z procesami zachodzącymi w ciele. Kwestie podjęte $w$ teorii umysłu rozszerzonego są zgodne z założeniami percepcji środowiska szkockiego antropologa. Enaktywna relacja poznania środowiska jest jego nieodłączną częścią.

\section{Koncepcja percepcji środowiska}

Koncepcja percepcji środowiska Ingolda składa się z trzech głównych elementów: życie w ruchu, zamieszkanie oraz kształtowanie umiejętności. Rozpocznijmy od charakterystyki rozpoznania ruchu życia w przestrzeni (Ingold 20oo). Rozpoznanie to sprowadza się do wyczucia niewyraźnych granic pomiędzy rzeczami i „podłączenia się" pod ich naturalny rytm. Percepcja środowiska odnosi się więc do odczuwania życia w ruchu w przestrzeni i może wymagać wyostrzenia w sobie pewnej wrażliwości przestrzenno-zmysłowej.

Ingold zauważa, że dla Gibsona życie mogło być prowadzone na ziemi, gdzie ziemia stanowi podstawową powierzchnię percepcji środowiska (Ingold 2000: 95-97).
W koncepcji Gibsona, ziemia stanowiąca grunt pod nogami dla organizmów żywych ma afordancję stania na niej (stand-on-able), chodzenia po niej (walk-on-able) oraz biegnięcia po niej (run-on-able). Szkocki antropolog nie ogranicza się jednak do percepcji powierzchni rzeczy i zauważa, że organizmy wcale nie żyją na ziemi, lecz w niej samej (in-the-world). Żywy, oddychający organizm jest rozpatrywany w kategoriach ciała w powietrzu i w ziemi (Ingold 2007). Przykładem wyraźnego życia w ziemi są rośliny i ich korzenie. U wszystkich jednak organizmów żywych z każdym wdechem, z każdym krokiem łączone jest to, co w powietrzu i to, co w ziemi.

Ingold zwraca uwagę na to, że żywy organizm opisuje się jednak zwykle jako zestaw komórek, który ma wyraźnie określone części wewnętrzne i zewnętrzne (Ingold 200o). Granicę pomiędzy nimi tworzą różnego rodzaju błony, czyli powierzchnie, które wchodzą w interakcje ze środowiskiem. To medium, np. powietrze, umożliwia lokomocję, respirację oraz percepcję. I właśnie dlatego Ingold zauważa, że to w medium zacierają się granice pomiędzy organizmami i w nim stają się one wyraźnie niewyraźne, stają się bowiem organizmami w środowisku. Ingold ilustruje to zjawisko na przykładzie życia wokół drzewa: „Drzewo ma korzenie w ziemi, pęczniejący pień i rozłożyste gałęzie, które w zależności od sezonu - pokryte pąkami lub liśćmi - kołyszą się na wietrze. [...] Jeśli ułamię kawałek kory i przyjrzę mu się uważnie, bez wątpienia odkryję, że jest ona zamieszkiwana przez wiele małych istot, które się w niej zagrzebały i uczyniły tam swój dom. Czy one są częścią drzewa? Czy są nimi mchy i porosty obrastające drzewo? Jeśli zgodzimy się, że owady, które toczą swoje tunele w korze, należą do drzewa tak samo jak sama kora, to nie ma żadnego specjalnego powodu, aby wykluczać pozostałych mieszkańców [...]. Jeśli w dodatku przyznamy, że natura tego drzewa leży także w tym, jak reaguje ono na powiewy wiatru kołysaniem gałęzi, szelestem liści, wtedy musimy przyznać, że drzewo nie 
może być niczym innym niż drzewem-w-powietrzu (tree-in-the-air)" (Ingold 2010: 4; cytat za: Wala 2016: 204).

Mówienie więc o drzewie, chmurze czy kamieniu, odnosząc się do percepcji środowiska, byłoby niezupełne bez uwzględniania medium - powietrza w przypadku drzewa - umożliwiającego wzrost i zmianę stanu rzeczy ${ }^{4}$. To w relacjach w medium organizm reaguje ze środowiskiem, stąd też szkocki antropolog odnosi się raczej do drzewa-w-powietrzu (tree-in-the-air), niebie-w-procesie-formowania (sky-in-formation), czy otoczaku-w-wodzie (stone-in-the-water) (Wala 2016: 204). W ujęciu życia w ruchu właściwości rzeczy zmieniają się pod wpływem sił i naporów w medium (za: Deleuze i Guattari 2004; Ingold 2011: 210-213) ${ }^{5}$. Ingold jest zdania, że świat nie jest kształtowany w kategoriach materii i formy, lecz w kategoriach materiałów i sił. W tym świecie rzeczy nie tyle są, co podlegają stałym procesom formowania się, a ich kształt ulega nieustannej relacji medium i substancji, sił i materiałów (Ingold 2010). Ingold odchodzi więc od arystotelesowskiego pojęcia hylemorfizmu, w którym to forma kształtuje materię, i zwraca uwagę na to, że sama forma również „żyje i reaguje ze środowiskiem", i w związku z tym podlega stałym przemianom. Życie natomiast dla Ingolda widziane jest tam, gdzie jest ruch: „Tam gdzie jest życie, jest i ruch. Nie każdy ruch jednak oznacza życie. Ruch życiodajny jest równoznaczny z procesem stawania się, nie zaś samego bycia”. (Ingold 2006: 15).

Dla Ingolda proces stawania się jest dostrzegalny w krajobrazie środowiskowym. Doświadczenie takiego krajobrazu nie

4 Ingold używa terminu „rzecz” do czegoś zdolnego do zmiany swojego stanu poprzez oddziaływania środowiskowe. Szkocki antropolog unika określenia „obiekty” - są one dla niego czymś sztucznym, nienamacalnym i martwym.

5 Deleuz i Guattari, których koncepcje świata w ruchu inspirowały Ingolda, używali pojęć comings i goings, stąd też pojawia się u niego pojęcie sił i naporów powodujących owe "przybycia" i „odejścia". ogranicza się jednak do zmysłu wzroku. W koncepcji ingoldowskiej organizm doświadcza całościowo drzewa-w-powietrzu czy otoczaka-w-wodzie. Świat jest więc subiektywnie doświadczany w swoim naturalnym ruchu w przestrzeni. Co więcej, organizmy i rzeczy w środowisku ruszają się w zmieniających się warunkach pogodowych. Jako przykład namacalnego wyczucia wiatru Ingold proponuje puszczanie na wiatr latawca. Wiatr wznosi narzędzie, przy czym nie odnosi się do sprawczości (agency) ani wiatru, ani latawca, lecz do ich wzajemnej interakcji (Ingold 2ooo). Doświadczenie świata w różnych stanach pogodowych Ingold nazywa „przechodzeniem-przez-świat-poprzez-pogodę (walking-through-the-weather-world). Środowisko podlega ciągłym zmianom przede wszystkim dlatego, że jest ono zanurzone w przepływach medium - w promieniach słońca, strugach deszczu, porywach wiatru i tak dalej” (Ingold 2011a: 131). Dlatego też: „Powinniśmy porównywać środowisko nie do pojemnika lub kurtyny, w którym albo za którym toczy się życie, lecz raczej do rzeźby lub pomnika, z uwzględnieniem dwóch okoliczności: po pierwsze, środowisko nie jest kształtowane ręką jednego twórcy, lecz wielu; po drugie, akt twórczy nigdy się nie kończy. Żadne środowisko nie jest (i nigdy nie będzie) ukształtowane w pełni. Podlega permanentnemu procesowi zmiany. Było, jest i będzie „rzeczywistością w trakcie stawania się"' (Ingold 2005: 82-3).

Po śladach ruchu zostawionym w środowisku przez wielu twórców można wnioskować o życiu, które tam było i/lub jest. Uważne odczuwanie podąża za śladami życia i formowania się świata. Wedug Ingolda, zatrzymanie się na chwilę i zwrócenie uwagi na kontekst środowiskowy pozwala na zdanie sobie sprawy z upływającego czasu wskazującego zmiany w zachodzących relacjach pomiędzy rzeczami w środowisku (Ingold 200o). Co więcej, dla Ingolda zmiany w środowisku dokonują się nie tylko przez samoistne podmuchy powietrza, lecz także same organizmy żywe, poruszając się, ingerują 
w ruch wiatru i tym samym kształtują rytm środowiskowy. Całościowa kompozycja ruchu jest rodzajem przestrzennego obrazu formowania się rzeczy w działaniach sił i i naporów na substancje. Ślady takich oddziaływań organizmów Ingold nazywa "śladami-stóp-w-świecie-poprzez-pogodę" (footprints-in-the-weather-world) (Ingold 2010).

Pozostawienie-śladów-w-świecie-poprze$z$-pogodę łączy się w koncepcji Ingolda ze śladami zamieszkania przestrzeni. Szkocki antropolog odróżnia perspektywę budowania od perspektywy zamieszkania środowiska, ponieważ nie zgadza się z podejściem, w którym środowisko miało by być najpierw budowane, a dopiero później zamieszkane (Ingold 200o). Dla niego zamieszkanie jest rodzajem nieustannego kształtowania się środowiska. Budowanie pozostawia po sobie konstrukcje statyczne, które nie wpisują się w odpowiednie określenie ciągłych zmian zachodzących w środowisku. Żyjąc, organizmy kształtują to, co jest wokół nic, i pozostawiają po swoich działaniach ślady. Ślady te wynikają jednak z wcześniej obranych odniesień środowiskowych. W języku ingoldowskim zamieszkana przestrzeń tętni rytmem osobistych odniesień do rzeczy w niej się stających.

Uwaga skoncentrowana na rozpoznawaniu śladów tych odniesień może być systematycznie ukierunkowywana przez osobę doświadczoną w zamieszkaniu danego środowiska. Ingold podejmuje w ten sposób myśl Gibsona o rozwijaniu zmysłu dostrzegania rzeczy w środowisku, czyli kierowania uwagą. W ten sposób można rozwijać zmysł dostrzegania oddziaływań pomiędzy rzeczami i powiązań w żywych obrazach. W koncepcji ingoldowskiej jednak dopiero ruch i rozpoznanie samego poznającego stanowi podstawę bezpośredniego doświadczenia i pojęcia zamieszkania środowiska. Co więcej, Ingold dostrzega, że rozpoznanie i zamieszkanie świata natury może być połączone z kulturowym ujęciem środowiska. Przykładem łączenia kultury i natury jest przeżywany przez plemię Walbiri Czas
Snu (Dreaming). Ingold w swojej koncepcji nawiązuje do opisywanych przez Mervyn Meggit ludzi zamieszkujących centralną Australię (Ingold 200o). Dzięki marzeniom sennym młodzi chłopcy w procesie inicjacji, wejścia w dorosłość, mają okazję osobiście przeżyć historię swojego środowiska naturalnego. Dla nich marzenie senne to stan człowieka, w którym doświadcza on wyższych metafizycznych przeżyć, uprzednio słuchając instrukcji i poleceń starszych braci. W towarzystwie przewodników, męża siostry i starszego brata, chłopiec przeprowadzany jest przez środowisko, gdzie przekazywana jest mu opowieść naporów sił i materiałów świata naturalnego, które stoją u źródeł powstałego środowiska. Każda historia ma swój czas refleksji, „zamkniętych oczu” i osobistego doświadczenia. Dla członków plemienia Walbiri właśnie tam, pomiędzy jawą a snem, kształtuje się indywidualna relacja rozpoznania sposobu zamieszkania przestrzeni i możliwość kształtowania osobistych odniesień do świata przyrody. Percepcja środowiska jest rodzajem sieci miejsc połączonych ze sobą przebytymi ścieżkami.

Poczucie wspólnie zamieszkanej przestrzeni jest rodzajem czucia łączenia rytmów kultury i natury. Procesy poznawcze, takie jak myślenie, doświadczanie, pamiętanie i uczenie się, są więc rozpatrywane z uzwględnieniem ekologicznego kontekstu nieustannych relacji wspólnego mieszkania w środowisku (Ingold 200o). Świat społeczny obejmuje subiektywne odniesienie do środowiska, widzenie jednak tych samych bądź podobnych afordancji rzeczy tworzy wspólną sieć społeczną. Wspólnie tworzone środowisko jest środowiskiem wspólnie zamieszkałym.

Według Ingolda, człowiek kultury jest przede wszystkim zakorzeniony w naturze. W swoim artykule Dreaming of Dragons (Ingold 2013) Ingold rozwija średniowieczną metaforę Natury jako Księgi, którą trzeba nauczyć się czytać. Można ją rozumieć jak traktat zawierający rozbudowaną treść naukową. Antropolog nawiązuje do łacińskiego słowa tractare, które oznacza przechodzić, 
przemierzać. Przemierzanie przez treść ma funkcję wyjaśniającą, porządkującą i kształtującą nowy sposób rozumienia rzeczy. Podobnie, przemierzając poprzez środowisko, można odkrywać, rozpoznawać i porządkować zachodzące w nim ciągi przyczynowo-skutkowe. Żeby pojąć obraz ptaka wraz z jego dźwiękiem, nie wystarczy o nim przeczytać, trzeba go doświadczyć, usłyszeć i zobaczyć. Poznanie wymaga czasem „wypraw pod prąd”, a to znaczy do źródła natury, która „nosi” w sobie wiele śladów i znamion swojego stawania się. Młodzi ludzie żyją w środowisku umeblowanym rzeczami przez swoich przodków. Co znaczy, że żyją w świecie połączeń naturo-kulturowych swoich przodków. Lud Walbiri pozwala jednak młodym, aby sami tworzyli i przeżywali odpowiednie powiązania między wydarzeniami środowiskowymi, dbając jednak o to, by warunki środowiskowe poznania były podobne do tych przekazywanych przez wieki.

Percepcja środowiska nie kończy się na nadawaniu znaczenia. Sposób rozumienia środowiska wpływa na działanie w nim. Tutaj myśl Ingolda łączy się z ideą „łączenia budowania i myślenia” Heideggera. Myśląc i nadając znaczenie, człowiek kieruje swoim działaniem. Ślady zamieszkania mają dwie warstwy: myślenia i działania (budowania). Według Ingolda, jako wspólni twórcy, żywe organizmy zamieszkując różne środowiska, tworzą w nich obszary powiązań wzajemnych działań, które w percepcji środowiska określane są mianem „dziełokształtu”6 (taskscape) (Ingold 2000: 194). Dziełokształt jest śladem zamieszkania środowiska przez kształtowanie umiejętności poruszania się w nim i obchodzenia się z materiałem. Oznaki zamieszkania wyłaniają się z umiejętności, wprawy działania, rozpoznania i wyczucia rzeczy.

Według Ingolda, kształtowanie umiejętności poruszania się i posługiwania narzędziami wymaga postrzegania życia w ruchu

6 Ingold często używa określenia "tkaniny” (meshwork) do zobrazowania sposobu przeplecenia się ze sobą indywidualnych ścieżek doświadczenia. oraz poczucia zamieszkania środowiska (Ingold 200o). Nabywanie umiejętności wymaga nieustannego wyczucia rytmu swojego środowiska. Czasem jednak rozpoznanie rytmu jest możliwe tylko dzięki załamaniu się oczekiwań względem zaplanowanego działania. Henri Lefebvre w Analizie Rytmu (Lefebvre, 2004), do którego nawiązuje Ingold, analizuje rytm jako coś odmiennego od automatycznego wykonywania określonej sekwencji ruchów. Powtarzanie jest pełne delikatnych, ledwo wyczuwalnych różnic, gdzie jednak każdy ruch pozostaje rytmiczny. Sam rytm wywodzi się z nieustannego korygowania wykonywanych gestów względem nieidealnych ruchów. Co więcej, Ingold zauważa również, że praca z rytmem wymaga ciągłej koncentracji (Ingold, 2011a, za: Wendrich, 1999).

Kolejne charakterystyki kształtowania się umiejętności, nawiązują do relacji podporządkowywania się pomiędzy wyobraźnią, a postrzeganiem, dążeniem do czegoś, a pojmowaniem tego czegoś, wystawianiem się na działanie, a dostrajaniem do działania (Ingold, 2014). Kształtowanie się umiejętności wymaga szczególnie tego ostatniego, wystawienia się na działanie i dostrojenia do tego co się dzieje: Wypychając tódkę na jezioro, licze na reakcje moich władz postrzegania zmystowego. Jednak wtaśnie $w$ tej reakcji odkrywam, że już kiedyś mi się to zdarzyto (...). Nie myślac nawet o tym, mam wrażenie, że wiem o co chodzi. Kierując się w jakąs strone, ku jakiemuś „jeszcze nieznanemu”, wiem, jak to dziata. Zatem podleganie jest w całości pamiętaniem. (...) Wydaje się, że w każdym przedsięwzięciu $i$ w każdej chwili jesteśmy zarówno w petni przygotowani, jak i jeszcze calkowicie niegotowi do rzeczy, które maja nadejść. (Ingold, 2014). Kształtowanie się umiejętności wychodzi więc z powtarzania. Wykonywanie czynności nie musi być z góry doskonale zaplanowane i określone, ale poddane pamięci ciała. Wychodzi to z nadawania znaczenia łódce, jej znajomości prowadzącej do przewidywania jak zachowa się na wodzie. Znaczenie ma wiatr (przechodzenie w świecie poprzez pogodę), i woda, 
i osoba w łódce i jej pamięć mięśniowa, a przede wszystkim zaufanie do relacji pomiędzy nimi. Kształtowanie umiejętności wymaga jednak podejmowania wielu prób: „Podporządkowanie zachodzi wcześniej, a mistrzostwo po nim. Edukacja wystawienia się na działanie poprzedza edukację opartą na dostrojeniu. Zamiast wydającego polecenia umysłu, który wie jaka jest jego wola, i zgodnie z nią świadomie pociąga za sobą podporządkowane ciało, na prowadzenie wysuwa się dążąca ku czemuś wyobraźnia, która wyczuwa wiodącą na przód drogę, improwizując szlak prowadzący przez jeszcze nieukształtowany świat, podczas gdy za nią podąża pojmująca percepcja, przyzwyczajona już do tego świata i jego sposobów istnienia, umiejąca go obserwować i reagować na stwarzane przezeń możliwości." (Ingold, 2014). Ingold w kwestii dotyczącej kształtowania się umiejętności sięga również do wyobraźni, możliwości widzenia stanów rzeczy zanim zostaną one urzeczywistnione. Wyobraźnia jest odniesieniem do myślenia kierującego poznaniem zmysłowym, które jest weryfikowane podczas działania. Szkocki antropolog odnosi się do pojęcia wiedzy-poprzez-działanie (knowing-by-doing) (Ingold, 200o). Dla niego kształtowanie się umiejętności może nastąpić tylko w przypadku odbywania praktyki działania. Umiejętne działanie ulega korespondencji z sytuacją, rzeczą, czyli wyczuwania rytmów środowiskowych i „podłączania się" pod nie w danym momencie (Ingold, 2011a).

W działaniu człowiek często posługuje się narzędziem. Posługiwanie się narzędziem wymaga uważnego wyczucia (a.) różnicy jakościowej pomiędzy sekwencyjnym, a procesualnym rozumieniem użycia narzędzia, (b.) synergicznych oddziaływań pomiędzy osobą posługującą się narzędziem, samym narzędziem i używanym materiałem, oraz (c.) nakładania się perceptów środowiskowych z ruchem osoby (Ingold, 2011a). Samo ciało jest rozumiane jako narzędzie, które podlega enakcji ze środowiskiem, stąd też można mówić o ucieleśnieniu doświadczenia zamieszkania w otoczeniu i wzrastaniu w wiedzę (Ingold, 200o).

Wyczucie procesualności użycia narzędzia opiera się na tym, że kształtowanie umiejętności nie wynika $\mathrm{z}$ ruchów będących następstwem poprzednich, lecz są one rozumiane w kategorii jednego wspólnego procesu raz podjętego działania. Dla Ingolda, w ruchu każdy krok rozwija się na bazie poprzedniego i jest już przygotowaniem na następny. Przecięcie deski może więc być rozumiane jako podróż z miejsca na miejsce. Dzieje się tak, gdy patrzy się na wykonywaną czynność poprzez ruch, jej rytmiczność i powtarzalność (Ingold, 2011a). Według Ingolda podróż ta zawiera się w etapach zamysłu działania, wyciągnięcia narzędzi, samego działania i uznania wykonanego zadania za skończone. Ich granice nie są jednak wyraźnie określone. Samo wykonanie jakiegoś zadania wymaga przygotowań, myśli o tym, co ma być przygotowane, jak zrealizować zadanie, jakich narzędzi i materiałów użyć ${ }^{7}$ (Ingold, 2011a). Do kształtowania umiejętności należy uwzględnianie konkretnych ruchów w kontekście całego działania. Sam zamysł działania potrzebuje osadzenia w szerszym, funkcjonalnym tle, nie tylko $w$ głowie (Leudar and Costall, 1996:164; Ingold, 2011a: 54), np. wymierzanie materiału. Czas realizacji wymaga głównie poddania się rytmowi samego działania (Ingold, 2011a). Kształtowanie umiejętności wymaga pracy z narzędziem i materiałem, nie przeciwko nim. Wraz z postępującym działaniem zmienia się nasilenie uwagi. Najpierw trzeba wywarzyć swoje działanie względem całej deski, samo cięcie ogranicza się już do miejsca przecinania jej. Wszelkie odstępstwa od zaplanowanego efektu końcowego mogą zostać zaakceptowane bądź poprawione (Keller, 2001: 35; Ingold, 2011a: 54). Odłożenie narzędzia staje się bowiem nowym początkiem (Ingold, 2011a).

7 Charles Keller nazywa taki plan parasolowym. Uwzględnia w nim styl, funkcjonalność, procedurę i samo wykonanie określonego działania. (Ingold, 2011a: 54) 
Występuje synergia pomiędzy użytkownikiem, narzędziem i materiałem. „Potrzebuję koziołka, rąk, swoich kolan aby ująć cięcie i utrzymać deskę w jednym miejscu. Potrzebuję każdego mięśnia swojego ciała aby dostarczyć sił pile i utrzymać balans podczas pracy. Potrzebuję również oczu i uszu aby nieustannie monitorować progres" (Ingold, 2011a: 56). Funkcje rzeczy są historiami swojego użycia, bycia w kontekście innych rzeczy, z którymi reagują. Kształtowanie umiejętności to zręczne wyłapywania tych historii, które jest zawsze tworzone de novo, z uwzględnieniem, ciągle zmieniających się warunków czasu teraźniejszego. Dodatkowo, każde użycie, jest przypomnieniem swoich poprzednich zdarzeń wrzucanych do obecnego kontekstu (Ingold, 2011a: 57). Umiejętna praktyka jest opowieścią działania. Podobnie jak ręce wykonują gesty, same gesty są tym, co tworzy ręce. Gesty tworzą też narzędzia, ich historie stawania się i użycia. Zręczność, wprawa wywodzi się z multisensorycznego dostrojenia się do zaistniałych sytuacji. Rytm ruchu tam i z powrotem jest rodzajem ruchu naturalnego. Płynność działania ma swoją rytmiczną jakość. Jego jakość nie ogranicza się jednak do powtarzalności samego ruchu, ale do wyczucia go. I właśnie to czucie jest rodzajem nakładania się na siebie ruchu i percepcji, które są kluczem umiejętnej praktyki. Umiejętna praktyka nie jest prowadzona przeciwko statycznemu kontekstowi, ale w świecie cyrkulacji różnych sił na siebie nachodzących. Rytm jest rodzajem dynamicznego łączenia ruchów. Każdy taki zabieg jest relacją synergiczną użytkownika, narzędzia i surowego materiału. Obcowanie z narzędziem uczy więc postrzegania siebie, narzędzia, materiału i środowiska.

\section{Studium przypadku: materiał i las}

Ta ogólna charakterystyka koncepcji percepcji środowiska i działania w nim może być zilustrowana przykładem podejścia ekologicznego do materiału i percepcją lasu. Analiza ekologicznego ujęcia materiału będzie oddolnym rozpatrzeniem percepcji środowiska. Percepcja lasu, dla kontrastu, będzie ujęciem odgórnym percepcji środowiska, próbą ujęcia percepcji określonego środowiska w całości.

Podejście ekologiczne do materiału z perspektywy percepcji środowiska jest rozwinięciem założenia o sposobie kształtowania umiejętności. Uchwycenie nietrwałości materiałów, z połączenia których stają się rzeczy w świecie, stanowi dla Ingolda podstawę aktualizowania umiejętności postrzegania środowiska i posługiwania się w nim narzędziami (Ingold, 2011a).

Ingold w percepcji środowiska zajmuje się procesem nadawania formy materiałom. Kształtowanie formy wymaga uważnych obserwacji materiałów i zmian ich stanów zachodzących w czasie. Ingold zauważa, że sama forma zmienia się w zależności od kontekstu, w którym jest kształtowana. Gilbert Simonton, na którego powołuje się Ingold, postuluje, że rzeczy generują się, i ich percepcja powinna ująć ten proces. W procesie ontogenezy rzeczy, forma wyłania się, nie jest z góry narzucona. W koncepcji Simontona materia nie przyjmuje pasywnie kształtu formy. Sam materiał wpływa na odkształcenia formy. Kiedykolwiek mamy do czynienia z materią, jest ona substancją w ruchu, zależną od czynników środowiskowych, w przepływie, zmienności (Ingold, 2011a; za Deleuze i Guattari, 2004).

Na drewno można patrzeć jak na materiał na dom, mebel bądź instrument. Możliwości drewna sięgają jednak dalej - może ono służyć jako opał do domowego kominka. W zależności od wrażliwości doświadczającego materiału, drewno może być przedmiotem zadumy i filozoficznych dociekań, czy też niewysłowionego poczucia piękna i estetyki. Drewno mogłoby być więc czymś na wyciągnięcie ręki i bezkresu wyobraźni. To, do jakich afordancji drewna człowiek się odwołuje, zależy od tego czego w danej chwili mu potrzeba (Ingold, 200o: 166-168: za Gibson, 1979). Tak jak każde narzędzie jest przypomnieniem swojego użycia, tak samo nosi na sobie ślady procesu swojego stworzenia i poprzedniego życia - stanowienia części zamieszkałej przestrzeni (Ingold, 2ooo). Myśl 
ekologiczna żywotności rzeczy odnosi się do tego, że drewno, z którego jest wykonane narzędzie, np. skrzypce, żyje, ma swoją historię, i że można ją odtworzyć na podstawie śladów. Szkocki antropolog nawiązuje do myśli Brendy Farner, która mówi o tym, aby na materiał patrzeć z jego perspektywy (Think from rather than about the body) (Brenda Farnell 2000). W drewnianym narzędziu znajdujemy ścieżki percepcyjne, które wiodą czujne oko, ucho, czy dłoń z powrotem do lasu, do tych drzew, z których powstały instrumenty, z którymi w danej chwili obcujemy. Przy dłuższym spotkaniu możemy poczuć jak współpracują ze sobą różne części materiału. Obcowanie z instrumentem uczy człowieka reakcji drewna z wilgotnością powietrza czy temperaturą otoczenia. Poznaniem nazywamy tutaj prowadzone odkrywanie rzeczy. Człowiek podążając za śladami w materiale może odbyć kilka retrospekcyjnych wędrówek do lasu.

Według założeń Ingolda percepcja lasu zaczyna się od dostrzeżenia żywotności lasu i nieustannego ruchu w nim. Uważne obserwacje prowadzą do spostrzeżeń o niewyraźnych granicach między rzeczami i wyraźnych powiązań między wodą, ziemią, powietrzem i ogniem. Las ma swoich stałych mieszkańców, żyjących według naturalnego rytmu przyrody. Odczuwanie zamieszkania środowiskowego, zgodnie z założeniami teoretycznymi Ingolda, jest związane z rozwijaniem zmysłu czucia otoczenia wszystkimi zmysłami. Człowiek, będący organizmem-w-środowisku uczy się rozpoznawać te rytmy w śladach-(pozostawionych)-w-świecie-poprzez-pogode (footprints-through-the-weather-world). Co więcej, wędrując w świecie, organizm ludzki również pozostawia ślady swojego poznania. Jednak rozpoznanie przeplecionych przez siebie śladów-w-świecie, czyli poszlak zamieszkania, może wymagać poświęcenia czasu i obserwacji środowiska. W eseju Sposoby poznania środowiska poprzez łowiectwo i zbieractwo, Ingold nawiązując do percepcji środowiska plemion zbieracko-łowieckich, które nazywa „dziećmi lasu', zauważa, że „Aby poznać las, rośliny i zwierzęta w nim zamieszkałe, człowiek potrzebuje nawiązać relację z danym fragmentem natury, podobnie jak zaznajamia się on z innymi ludźmi, poświęcając im jakościowo tyle samo troski, uczuć i uwagi" (Ingold, 200o: 47).

Według Ingolda, miejsce dla troski, uczucia jest w niewyraźnych granicach środowiska. Drzewo-na-wietrze rosnace w lesie to sieć wzajemnych oddziaływań pomiędzy solami mineralnymi zawartymi w ziemi, wodą kapilarnie przeciskającą się od korzeni przez łodygi aż do liści oraz światła promieni słonecznych niezbędnych dla procesów fotosyntezy i rozrostu rośliny. Poznanie drzew w lesie wymaga co najmniej kilku spotkań w różnych okresach pogodowych, o różnych porach dnia i nocy. Zimą na przykład przez nagie gałęzie drzew przeszywa się ostry dźwięk wiatru. Wtedy również widać wyraźniej jak zbudowane jak rozgałęzienie drzewa, jego kontury mogą być nawet pokryte warstwą śniegu. Latem w koronach drzew biegają wiewiórki, po korze chodzą mrówki a w korzeniach mieszkają rysie. Kilka spotkań pozwala odczuć cykliczność przyrody. Spotkania nie muszą odbywać się w milczeniu i bezruchu. Uważna obserwacja nie ogranicza się do bycia w bezruchu. Skoro świat poznawany tętni życiem w ruchu, to należałoby również w tak naturalny sposób go poznawać. „Przechodnia” percepcja lasu może odbyć się na boso (Ingold, 2011a). Spacer bosymi stopami może być wyraźnie skupiony na odczuwaniu przestrzeni w ruchu. Nieprzyzwyczajona do bosych wędrówek stopa jest wyraźnie wrażliwa na odczuwanie przestrzeni leśnej: wilgotnego podłoża, suchych jesiennych liści czy miękkiego mchu. Ściągając buty zmniejsza się dystans pomiędzy uważnie obserwującym a obserwowanym żywym obrazem przyrody. Tak pojawia się przestrzenność odczuwania obrazów leśnych (odczuwania-śladów-w-świecie) (Ingold, 2011a). Umiejętne rozpoznanie śladów zamieszkania środowiska prowadzi do poczucia zostawiania swoich własnych śladów. Ślady swoich stóp można ująć w postaci metafory pająka tkającego pajęczynę, 
stanowiącą namacalny ślad swoich środowiskowych wędrówek. Tkając pajęczynę własnych powiązań, człowiek zamieszkuje w przestrzeni, w której znajduje się, tworzy w ten sposób swój punkt odniesienia dla środowiska, w którym znajduje się. To ruch w pajęczynie łączy ze sobą percepty intelektualne ze zmysłowymi i rozbudowywanie sieci znajomości rzeczy. Pojawiają się ciekawość i niepewność poznawcza. Rozpoznając ciągi przyczynowo-skutkowe w przyrodzie i zamieszkując w środowisku, człowiek „wrasta w wiedzę" o otoczeniu, w którym znajduje się, i tak kształtuje swoje umiejętności. Proces ten jest dobrze opisany w metaforze pająka (spider). Jeżeli potraktujemy angielskie słowa SPIDER jako akronim, to jego rozwinięcie składa się z następujących słów Skilled Practice Involves Developmentally Embodied Response (Umiejętna Praktyka Obejmujęca Rozwojowo Ucieleśniona Odpowiedź), które oznaczają specyficzne cechy tego procesu. Bezpośrednie doświadczenie zamieszkania środowiska i orientowania się w nim, umiejętność posługiwania się narzędziami obejmuje trening reakcji ciała. Według Ingolda, pająk, tworząc sieć, musi przebyć drogę z każdej jej strony. Przebyte przez pająka drogi są namacalne i widoczne. Ingold zauważa, że pająk może poruszać się po swojej pajęczynie tam i z powrotem, ale doświadczenie przebywania tych dróg nigdy nie będzie takie samo. Zmienność ta jest spowodowana chociażby nietrwałością warunków pogodowych. Pajęczyna doświadczenia jest też zawieszona o drzewo lub gałąź, staje się fragmentem otoczenia. Pajęczyna jest podatna na zniszczenia i ruch wiatru. Będąc pajęczyną zawieszoną na drzewie, drzewo-na-wietrze, sieć doświadczenia łączy to, co w ziemi i to, co w powietrzu (Ingold, 2011a). To postrzeganie środowiska, łącznie z kierowaniem w środowisku uwagą organizmu, wpływa na sposób doświadczania życia w środowisku i kształtowania w ten sposób pajęczyny doświadczenia. Ingold odnosi się do spostrzeżeń Roya Wagnera mówiącego o tym, że na życie osoby składają się wszystkie drogi, które przemierzył, są one wpisane w jego ciało (Ingold, 2011a: 151; za: Wagner 1986: 21). Umiejętności kształtowane w percepowanym środowisku są opowieściami relacji synergii pomiędzy organizmem, narzędziem i środowiskiem. W zależności od tego $\mathrm{w}$ jakim otoczeniu jest organizm, takie kształtuje opowieści. Pajęczyna, którą człowiek w ten sposób przędzie, opiera się również o drzewo czy gałęzie stojące tuż obok niej. Sama pajęczyna również jest częścią większej całości. Podobnie drzewa potrzebują swoich korzeni i nie tylko po to by piąć się wysoko w górę, lecz również po to, aby współ-tworzyć sieci powiązań z dalszą częścią lasu.

Dla Ingolda zamieszkanie łączy się z kształtowaniem i tworzeniem, będącymi nieustannym wyważeniem odpowiednich sił na materie (Ingold, 200o). Zamieszkanie $\mathrm{w}$ środowisku związane jest $\mathrm{z}$ tworzeniem rzeczy, pielęgnacją roślin, hodowaniem zwierząt, a nawet wychowywaniem dzieci. Tworząc, osoba stwarza odpowiednie warunki do rozwoju swojego i rzeczy, z którymi obcuje. Ludzie, poświęcając wystarczająco dużo uwagi sobie nawzajem, zwierzętom, roślinom czy rzeczom, podlegają korespondencji z zamieszkałym środowiskiem. Intensywna korespondencja prowadzi do nabywania umiejętności rozumianej w kategoriach wzrastania rzeczy z uzmysłowionym organizmem, czyli kształtowania umiejętności poruszania się w umeblowanym świecie, tworzenia go oraz odpowiadania na zaistniały ruch środowiska. W ten sposób doświadczenie, z punktu widzenia kognitywistyki, staje się ucieleśnione.

\section{Podsumowanie}

Przedstawiona wyżej rekonstrukcja podstawowych kategorii filozoficznych i antropologicznych koncepcji percepcji środowiska odnosi się do wyróżnionego fragmentu antropologii środowiska Tima Ingolda, ponieważ dostarcza podstawowego schematu pojęciowego dla całościowego projektu antropologii kulturowej. Sformułowanie takich pojęć, jak życie w ruchu, zamieszkania środowiska oraz sposób kształtowania 
nowych umiejętności, stanowi o podejściu ekologicznym do zagadnień poznania i relacji uzmysłowionego organizmu do swojego środowiska. W podejściu tym uwzględnia się także nietrwałość powiązań środowiskowych, które powstają w wyniku enaktywnej relacji podmiotu poznającego ze środowiskiem oraz ideę poznania w ruchu.

Uchwycenie życia w ruchu według propozycji Ingolda łączy się z wyczuciem naturalnego rytmu poznawanego środowiska. Takie poznanie wymaga stałego rozwijania szeroko pojętej wrażliwości zmysłowej. W założeniach teoretycznych rozwinęliśmy myśl Ingolda dotyczącą przechodzenia-w-świecie-poprzez-pogodę oraz zostawiania śladów. W-świecie-poprzez-pogodę proces kształtowania się środowiska ulega stałej rekonstrukcji, a sieć osobistych powiązań rozwija się w nim wedle rozpoznawania i korzystania z dostrzeganych afordancji środowiska. Rozpoznanie tych możliwości, i korzystanie $\mathrm{z}$ nich wedle koncepcji miałoby wpłynąć na to, w jaki sposób człowiek jako uzmysłowiony organizm w środowisku, wpływa na rozwój swoich umiejętności i spostrzeżeń. Ostatnie z założeń, czyli sposób kształtowania umiejętności, opiera się na dwóch poprzednich tezach i odnosi się do rozwijania zdolności percepcyjnych poprzez działanie (knowing-by-doing). Wedle koncepcji, tak jak ślady działań organizmów są widoczne w środowisku, również ciało jako narzędzie poznania staje się nośnikiem swojego doświadczenia. Ucieleśnienie doświadczenia zostaje poprzedzone treningiem całego organizmu, na którym zostają ślady oddziaływań między organizmem a środowiskiem. Tak więc dynamika kształtowania się umiejętności jest w stałej relacji do środowiska, używanych narzędzi i rodzaju używanych materiałów.

Doświadczenie drzewa-na-wietrze o korzeniach-w-ziemi jest przykładem znajomości szerokiego kontekstu poznania w środowisku i zwracania uwagi na powiązania życia świata przyrodniczego. Takie przykłady aplikacji koncepcji pozostawiają kilka wskazówek do tego, jak można rozwijać sposób postrzegania środowiska przyrodniczego i praw nim rządzących. Warto pamiętać, że po ścieżkach leśnych można chodzić boso, z zamkniętymi oczami poddać się wyostrzeniu zmysłów i pozwolić sobie na rozpoznanie przestrzennych symfonii leśnej żywotności.

\section{Bibliografia}

Clark A., Chalmers D., (1998), Analysis. The Extended Mind. Volume 58, 7-19.

Ingold T., 1990: „Society, nature and the concept of technolog", Archaeological Review from Cambridge, 9, 5-17.

Ingold, T. (200o). Environmental Perception. Essays on Livelihood, Dwelling and Skills, London: Routledge.

Ingold, T. (2011a). Being Alive: Essays on Movement, Knowledge and Description. London: Routledge.

Ingold, T. (2010). Bringing Things Back to Life: Creative Entanglements in a World of Materials. NCRM Working paper. Realities / Morgan Centre, University of Manchester

Ingold, T. (2014) Człowiek to czasownik. Kolokwia antropologiczne. Problemy współczesnej antropologii społecznej/ pod red. Michała Buchowskiego i Arkadiusza Bentkowskiego. Poznań. Wydawnictwo Nauka i Innowacje.

Ingold, T. (2016). From Science to art and back again: The pendulum of an antrhropologist.. Auac.

Vol. 5. N. 1 Giugno. 5-23

Ingold, T. (2011b) Redrawing Antropology. Materials, Movements, Lines. Asgate, Farnham

Ingold, T. (2012) Towards Ecology of Materials. Annual Review of Antropology 41: 427-4.42

Trybulec, B. (2017). Wiedza i jej podmiot w szerokich systemach poznawczych. Warszawa, Wydawnictwo IfiS PAN

Ramirez Barreto A. C. (2009) Merleau-Ponty from Tim Ingold's perspective. Ontology and anthropology of interanimality. Revista de Antropologia Iberoamericana, Volumen 5, numero 1, s. 82-103

Wala, K. (2016). Utożyć świat na nowo. Rekonstrukcja koncepcji Tima Ingolda (cz. I). Etnografia. Praktyki, Teorie, Doświadczenia 2:189-209

Wala, K. (2014). Rytm, https://uzmyslowienie.wordpress.com/2014/o6/25/rytm/, data dostępu: 5.05 .2018 


\title{
Concept of the perception of the environment proposed by Tim Ingold
}

\begin{abstract}
The main concern on this article is the reconstruction of the concept of the perception of the environment proposed by Tim Ingold, cultural anthropologist from Scotland. The first part of the article is the illustration of historical and theoretical background of the concept of perception of the environment where the basic theoretical assumptions of Tim Ingold's environmental anthropology were introduced. The main points of the background knowledge are: the ecological approach to the visual perception of J. Gibson, the concept of Umwelt proposed by Jacob Johann von Uexküll, the dwelling perspective for environmental transformations of Martin Heidegger, the concepts of mind embodiment and extension. The reconstruction of the concept of perception of the environment is aimed at explication of three main ideas: the life in movement, dwelling perspective and new skill development.
\end{abstract}

The second part of this article is focused on the applications of the concept of perception of the environment in two case studies: the forest perception and the ecological approach to the materials.

\section{Keywords}

T. Ingold, perception of the environment, forest perception, the ecology of materials, environmental antropology 